\title{
Legal framework and current techniques for age estimation in puppy trade
}

\author{
Wettelijk kader en huidige technieken voor leeftijdsschatting in de puppyhandel
}

\author{
M. Van den Broeck, P. Cornillie
}

Department of Morphology, Faculty of Veterinary Medicine, Ghent University, Salisburylaan 133, 9820 Merelbeke, Belgium

martine.vandenbroeck@ugent.be

\begin{abstract}
$\Lambda_{\text {bstract }}$
Dog breeding and dog trade are strictly regulated by EU-legislation, as well as by national and regional legislations. Nevertheless, it is believed that part of the puppies traded within the EU are younger than the legal minimum age, with the risk of compromising their own health and wellbeing as well as public health. A proper age determination is necessary to expose potential malpractices. Combining multiple independent methods is essential to compensate for possible variations in one single estimation method. Assessment of the dental age and bone age, more specifically by evaluating the eruption status of the dentition and the radiographic appearance and formation of ossification centers are both eligible. However, current available data are not detailed enough. In order to improve the accuracy and reduce the error in age estimation, more breed specific data are required, more intermediate development stages must be described and possible developmental disorders and pathologies must be considered.
\end{abstract}

\section{SAMENVATTING}

Hondenfokkerij en -handel zijn strikt gereguleerd door EU-wetgeving en nationale en regionale wetgeving. Desondanks wordt aangenomen dat een deel van de verhandelde puppy's binnen de EU jonger is dan de wettelijke minimumleeftijd. Dit kan zowel de gezondheid en het welzijn van de pup als de volksgezondheid in gevaar brengen. Een juiste leeftijdsbepaling is noodzakelijk om mogelijke inbreuken aan te tonen. Het combineren van meerdere onafhankelijke methoden is essentieel ter compensatie van mogelijke variaties binnen één methode. Het vaststellen van zowel de gebits- als de botleeftijd, meer specifiek aan de hand van de eruptiestatus van het gebit en de radiologische ontwikkeling van ossificatiecentra, komen hiervoor in aanmerking. De huidige beschikbare gegevens zijn echter niet gedetailleerd genoeg. Om de nauwkeurigheid van de leeftijdsschatting te verhogen en fouten te vermijden zijn 1. meer rasspecifieke gegevens noodzakelijk, 2. moeten meer tussenliggende ontwikkelingsstadia beschreven worden en 3 . moet rekening gehouden worden met mogelijke ontwikkelingsstoornissen en afwijkingen.

\section{INTRODUCTION}

According to the Fediaf report of 2019, an estimated $25 \%$ of the European Union households owns at least one dog. The total number of owned dogs reaches 65.5 million (Fediaf, 2019). The figures for Belgium are comparable and have remained stable since 2012 at about $24 \%$ of the households (Van Bo- gaert, 2013; Fediaf 2017 - 2019; Statista 2019), with an estimated total of 1.3 million dogs (Fediaf, 2019). Of the 97.437 newly registered dogs in Flanders in 2018, 18.546 came from abroad (19\%) (Weyts, Flemish Parliament, 2019). A considerable part of these pups was imported from Eastern European countries. The main countries were: Slovakia $(11.570 ; 59 \%)$, the Czech Republic, (3.932; 20\%), Hungary (1.812; 


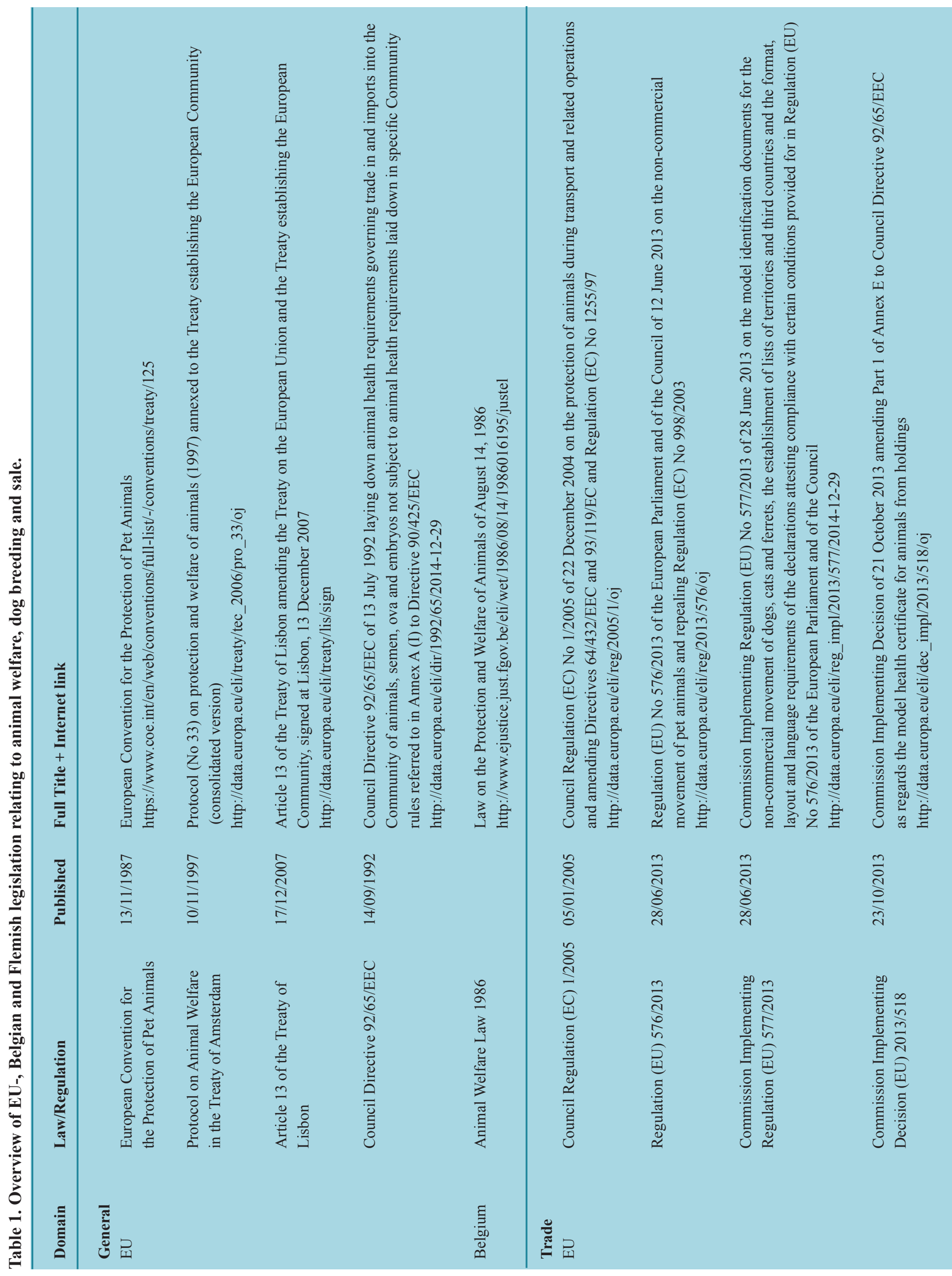




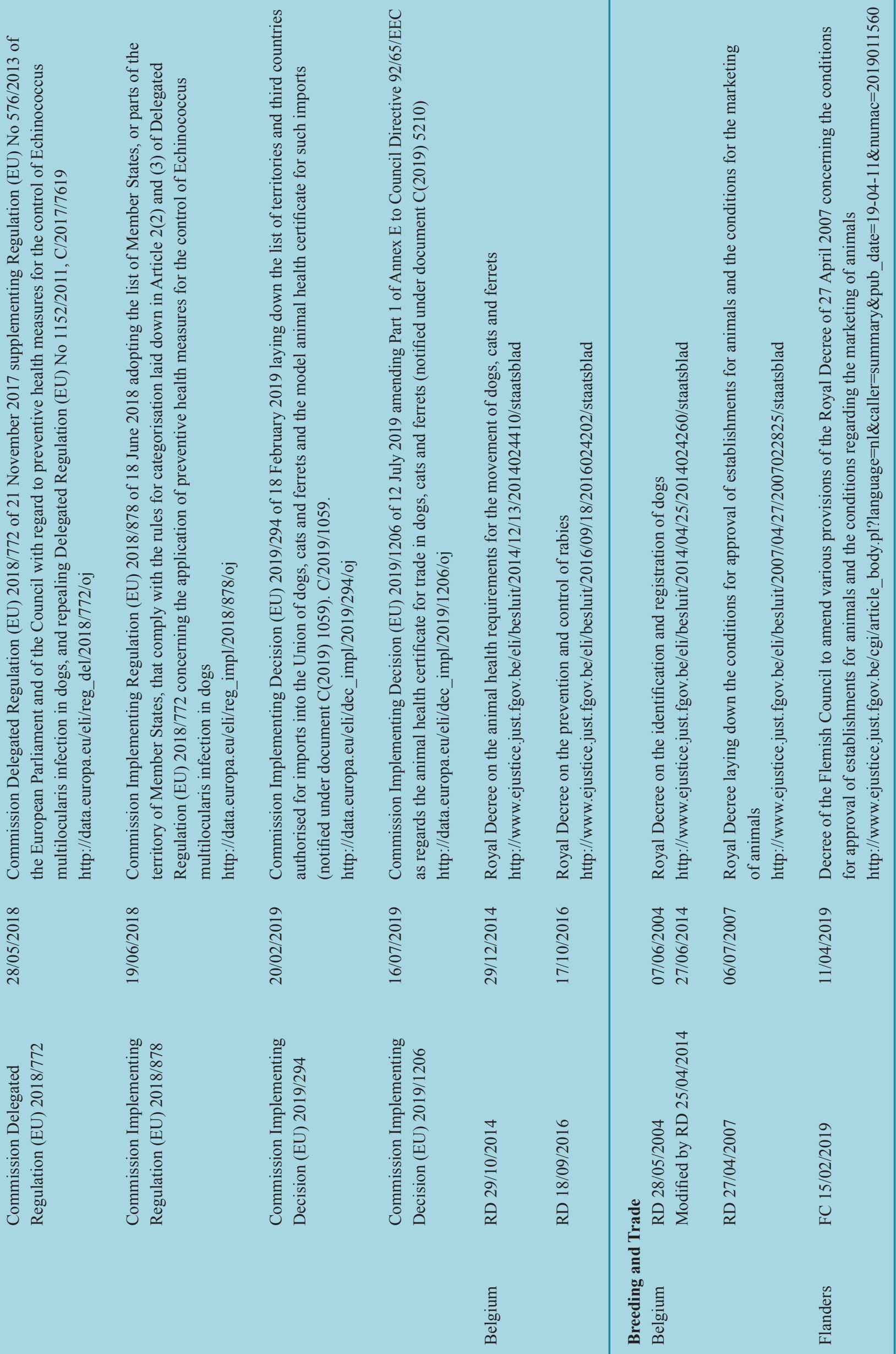


9.24\%), Spain (1.104; 5.6\%) and Romania (1.016; $5.18 \%$ ) (Ponsaerts, 2019). The annual value of cat and dog sales in the EU is estimated at 1.3 billion euro, generating direct employment for 300.000 people (Schrijver et al., 2015).

Buying a puppy is often an impulse purchase (Yeates and Bowles, 2017; Maher and Wyatt, 2019). Consumers are strongly attracted by the 'cute factor' of a puppy, making dogs most marketable at a young age (Yeates and Bowles, 2017; Chersini et al., 2018). According to the British Kennel Club (2017), 36\% of the British puppy buyers spend less than twenty minutes researching where to buy their puppy, with the risk of buying from an irresponsible source. Consumers who do not want to be put on a waiting list or who do not want to adopt a shelter dog, often turn to commercial breeders who have (often cheaper) puppies immediately available. The internet has become the principal source where to look for puppies for sale (Maher and Wyatt, 2019). It is more accessible, makes a rapid purchase possible and for many people comes across as more reliable (Wyatt et al., 2017). Puppy trade in Belgium is strictly regulated. In Flanders, only officially recognized breeders with a valid approval number can advertise on trading websites or social media. (Private) persons without approval number can only advertise via specialized media (specialized magazines or websites) (Animal Welfare Law, 2016), and are prohibited to sell dogs or give away for free via social media (official website Flemish Government, 2020). Compliance to these regulations is however very difficult to control (Lavorgna, 2015; Yeates and Bowles, 2017). Puppies are offered for sale in private groups or personal messages on facebook (Hus, 2018). Advertisements on trading websites can be misleading, for example by pretending to sell pups raised in a domestic setting when actually, the pups come from large breeding facilities (Hus, 2018).

Breeding and trading dogs is thus an important economic activity with potentially high profit mar-

Table 2. Different types and number of dog breeders in Flanders (on 28/02/2020) and the most important conditions* they must meet.

\begin{tabular}{|c|c|}
\hline Breeder type & Conditions (RD 27/04/07, adjusted** by FC 15/02/19) \\
\hline $\begin{array}{l}\text { Occasional breeder (occasionele kweker/ } \\
\text { éleveur occasionel) } \\
\mathrm{n}=?\end{array}$ & $\begin{array}{l}\text { - License number (HK number) not obligatory } * * * \\
\text { - Max. two litters/year } \\
\text { - May only advertise in specialized press (not on internet or social media) }\end{array}$ \\
\hline $\begin{array}{l}\text { Amateur breeder (hobbykweker/ } \\
\text { éleveur amateur) } \\
\mathrm{n}=732\end{array}$ & $\begin{array}{l}\text { - License number (HK number) obligatory } \\
\text { - Must issue a two-year guarantee certificate } \\
\text { - Max. five litters/year (1) } \\
\text { - Veterinary check at least two times/litter } \\
\text { - Can advertise on the internet if license number is stated. Ads with photos of } \\
\text { animals other than the animals offered are not permitted }\end{array}$ \\
\hline $\begin{array}{l}\text { Professional breeder (beroepskweker/ } \\
\text { éleveur professionnel) } \\
\mathrm{n}=122\end{array}$ & $\begin{array}{l}\text { - License number (HK number) obligatory } \\
\text { - Trades only dogs from own breeding } \\
\text { - Must issue a two-year guarantee certificate } \\
\text { - } \text { Can have more than five litters/year (1) } \\
\text { - The respon breeds (from } 01 / 01 / 2021)(2) \\
\text { or certificate (from } 01 / 01 / 2024 \text { ) } \\
\text { - Veterinary check at least once a month and at least two times/litter } \\
\text { - Can advertise on the internet if license number is stated. Ads with photos of } \\
\text { animals othan the animals offered are not permitted }\end{array}$ \\
\hline $\begin{array}{l}\text { Breeder-merchant } \\
\text { (kweker-handelaar/éleveur commerçant) } \\
\mathrm{n}=46\end{array}$ & $\begin{array}{l}\text { - License number (HK number) obligatory } \\
\text { - Trades dogs from own breeding and from other facilities } \\
\text { - } \text { At least ten litters of own breeding/year } \\
\text { - Max. seven own breeds (from } 01 / 01 / 2021)(2) \\
\text { - Puppies from other facilities are quarantined for at least ten days } \\
\text { - The responsible person or a permanent staff member has a recognized } \\
\text { diploma or certificate (from } 01 / 01 / 2024) \\
\text { - Can advertise on the internet if license number is stated. Ads with photos of } \\
\text { animals other than the animals offered are not permitted }\end{array}$ \\
\hline
\end{tabular}

* In addition to animal welfare regulations, dog breeders must also comply with environmental legislation: for keeping more than five 'dogs', a class 3 environmental license application is required (notification obligation), for keeping more than ten 'dogs', a class 2 environmental license application is required (license obligation) (Flemish environmental legislation VLAREM II). In this regulation, the term 'dogs' only applies to dogs older than six months. $* *$ These adjustments do not apply for breeders in Wallonia and Brussels, where - at the moment- the original conditions laid down in the royal Decree of 27 April 2007 still apply: (1) amateur breeder max. ten litters/year and professional breeder more than ten litters/year; (2) no restrictions on the number of dog

b** In Wallonia an occasional breeder - approval is obligatory (Decree of the Walloon Government of 11 May 2017). 
gins, which, combined with consumer buying behavior, can easily result in animal welfare being of secondary importance.

\section{LEGAL ASPECTS CONCERNING DOG BREE- DING AND TRADE}

A list of EU-, Belgian and Flemish legislations relating to animal welfare, dog breeding and sale can be found in Table 1.

Animals are recognized as sentient beings in European Union legislation (Protocol on Animal Welfare in the Treaty of Amsterdam, 1997; Article 13 in the Treaty on the Functioning of the EU or the Treaty of Lisbon, 2007). Very recently, also the Belgian Federal Parliament has adopted a revised Civil Code, recognizing animals as sentient beings (Chamber of the Belgian Federal Parliament, 2020; Weyts, Flemish Parliament, 2020). Although symbolically important, this recognition does not form any legal basis for animal welfare legislation. In legal terms, animals remain under the category of 'legal objects' and are considered as property subjected to property laws (Simonin and Gavinelli, 2019), albeit with special consideration on account of their well-being (Francione and Kunstler, 1994). At European level, general regulations for the protection of animal welfare were laid down in the European Convention for the Protection of Pet Animals of 13 November 1987 (Treaty 125 of the Council of Europe), ratified by Belgium in 1991. Specific measures are only formulated in EU legislation to ensure animal welfare during commercial transport (Council Regulation (EC) 1/2005). Although binding and applicable in all EU member states, there is little evidence that this regulation is equally being enforced (FECAVA et al., 2016). The responsibility for keeping and breeding pet animals remains with the national legislation of the individual member states (Schrijver et al., 2015) and may differ enormously amongst the member states (EU dog and cat alliance, 2015).

In Belgium, the Law on the Protection and Welfare of Animals of August 14, 1986 (the Animal Welfare Law) forms the basis for all other regulations that govern welfare in dog breeding and dog trade. Because of the regionalization of animal welfare in Belgium, different regulations may apply for the Flemish, Walloon and Brussels capital region.

Since October 1, 2019, the legal minimum age at which puppies can be weaned in Flanders, has increased from seven to eight weeks (FC 15/02/2019), out of consideration that the nesting period is a very important phase for the development and socialization of puppies. Puppies should stay long enough in a familiar environment with their mother and littermates. 'Long enough' may differ among breeds (Scott and Fuller, 1965; Morrow et al, 2015) but the maternal period should at least last until natural weaning occurs (Wilsson, 1984; Case, 2005). Early weaning interferes with the behavioral development (Elliot and Scott,
1961; Overall, 2013; McMillan et al., 2013; McMillan, 2017) and increases aggressive and abnormal behavior (Pfaffenberger, 1963; Fox and Stelzner, 1966; Lindsay, 2000; Pierantoni et al., 2011; Tiira et al., 2012). All puppies must also have had at least a primo vaccination against parvovirus, distemper virus, Bordetella and para-influenza virus (kennel cough) and hepatitis contagiosa canis virus before being sold (FC $15 / 02 / 2019$ ) and must be correctly identified. Dogs in Belgium have to be identified with a microchip and have to be registered in the central database DogID (https://dogid.be). The identification has to be linked to a European pet passport (for dogs born after June $\left.7^{\text {th }}, 2004\right)$. Puppies born in Belgium have to be identified before the age of eight weeks (RD 28/05/2004 and RD 25/04/2014).

Breeding facilities can range from occasional breeders selling only once or twice a litter, to commercial breeders selling thousands of pups a year. In Table 2, the different types of dog breeders in Belgium, in accordance to the royal decree (RD 27/04/2007) with the latest adjustments for Flanders (FC 15/02/2019) are shown. There are four types of breeders: the occasional breeder, the hobby breeder, the professional breeder and the breeder-merchant. Although dogs are now considered as sentient beings in the Belgian Civil Code, the sale of dogs still falls under the consumer protection law (consumer protection law of September 1, 2004). This means, among other things, that a two-year guarantee certificate must be issued by all legally recognized establishments (i. e. all but occasional breeders). Breeder merchants mostly resell pups from other breeders but are required to breed a minimum of ten own litters every year. The puppies they buy for further sale can either come from local breeders - occasional, hobby or professional - or from foreign breeders, provided that these breeders meet the required standards (recognized foreign breeders and breeders from countries whose legislation lays down at least the same conditions) (ad III(2) of RD 27/04/2007). The Belgian governments use a list of registered breeding establishments in Eastern European countries that meet these standards, although part of the breeders on the list are collection centers that resell local pups to Western European countries (Weyts, Flemish Parliament, 2015; Weyts, Flemish Parliament, 2018). Compliance to the established conditions is checked by veterinarians of the exporting countries (Flemish Department of Animal Welfare, 2020).

The import and export of dogs to and within the EU are subjected to specific regulations that are implemented in Belgium by the Royal Decree of $13 / 12 / 2014$. Distinction is made between commercial and non-commercial movements and between intraunion trade and import from non-European countries. Transports are considered commercial when 1 . the owner or a legal representative of the owner is travelling more than five days before or after the movement of the pet, 2. when the purpose of the transport invol- 
ves a sale or transfer of ownership or 3. when more than five animals are traveling with or without their owner (Regulation (EU) 576/2013).

As already mentioned, the welfare of animals during transport is regulated by Council Regulation (EC) $1 / 2005$. All dogs crossing borders have to be identified by microchip, accompanied by a valid (European) Passport (Regulation (EU) 576/2013 and Commission Implementing Regulation (EU) 577/2013) and have to be at least fifteen weeks old.
The latter results from the requirement that all dogs crossing borders should be correctly vaccinated against rabies (Regulation (EU) 576/2013, Directive 92/65/EEC and Commission Implementing Decision (EU) 2013/518). This prerequisite is in correspondence with the protocol of the anti-rabies vaccine manufacturers who state that a primo-vaccination only establishes a protective immunity when it has been administered at the age of at least twelve weeks, after which a three-week waiting period is taken into

Table 3. List of the prerequisites and legislation for the commercial and non-commercial transport of dogs.

\begin{tabular}{|c|c|c|}
\hline Types of transport & $\mathbf{E U}$ & non-EU \\
\hline Non-commercial & $\begin{array}{l}\text { Regulation (EU) 576/2013 and Commission } \\
\text { Implementing Regulation (EU) 577/2013 } \\
\text { - Must be identified with a microchip } \\
\text { - Must be accompanied by a valid pet passport } \\
\\
\text { Regulation (EU) 576/2013 and Council Directive } \\
\text { 92/65/EEC implemented by Commission } \\
\text { Implementing Decision (EU) 2013/518 } \\
\text { - Must be correctly vaccinated against rabies } \\
\text { - primo vaccination earliest at twelve weeks } \\
\text { - a three-weeks waiting period }\end{array}$ & $\begin{array}{l}\text { Regulation (EU) } 576 / 2013 \text { and Commission } \\
\text { Implementing Regulation (EU) } 577 / 2013 \\
\text { - Must be identified with a microchip } \\
\text { - Must be accompanied by a valid pet passport } \\
\text { Regulation (EU) 576/2013 and Council Directive } \\
\text { 92/65/EEC implemented by Commission } \\
\text { Implementing Decision (EU) } 2013 / 518 \\
\text { - Must be correctly vaccinated against rabies } \\
\text { - primo vaccination earliest at twelve weeks } \\
\text { Additionally: } \\
\text { Regulation (EU) No } 576 / 2013 \\
\text { - Rabies antibody titration test at least thirty days } \\
\text { after vaccination and at least three months before } \\
\text { transport } \\
\text { Regulation (EU) No 576/2013, Regulation (EU) } \\
\text { No } 577 / 2013 \text { ) } \\
\text { - Must be accompanied by a health certificate by } \\
\text { an authorized veterinarian and a written declaration } \\
\text { concerning non-commercial nature } \\
\text { - Must cross borders through a travellers' point of entry }\end{array}$ \\
\hline Commercial & $\begin{array}{l}\text { Regulation (EU) } 576 / 2013 \text { and Commission } \\
\text { Implementing Regulation (EU) } 577 / 2013 \\
\text { - Must be identified with a microchip } \\
\text { - Must be accompanied by a valid pet passport } \\
\text { Regulation (EU) 576/2013 and Council Directive } \\
92 / 65 / \text { EEC implemented by Commission } \\
\text { Implementing Decision (EU) } 2013 / 518 \\
\text { - Must be correctly vaccinated against rabies } \\
\text { - primo vaccination earliest at twelve weeks } \\
\text { - a three-weeks waiting period } \\
\text { Additionally: } \\
\text { Council Directive } 92 / 65 / E E C \\
\text { - Must come from registered holdings } \\
\text { Council Regulation (EC) No } 1 / 2005 \text {, Council } \\
\text { Directive } 92 / 65 / E E C \text { implemented by Commission } \\
\text { Implementing Decision (EU) } 2013 / 518 \\
\text { - Must be registered in TRACES (Trade Control } \\
\text { and Expert System) } \\
\text { - Must be accompanied by a health certificate } \\
\text { completed and issued by an authorized veterinarian } \\
\text { within } 48 \text { hours prior to transport }\end{array}$ & $\begin{array}{l}\text { Regulation (EU) 576/2013 and Commission } \\
\text { Implementing Regulation (EU) } 577 / 2013 \\
\text { - Must be identified with a microchip } \\
\text { - Must be accompanied by a valid pet passport } \\
\text { Regulation (EU) 576/2013 and Council Directive } \\
92 / 65 / E E C \text { implemented by Commission } \\
\text { Implementing Decision (EU) } 2013 / 518 \\
\text { - Must be correctly vaccinated against rabies } \\
\text { - primo vaccination earliest at twelve weeks } \\
\text { Additionally: } \\
\text { Regulation (EU) No } 576 / 2013 \\
\text { - Rabies antibody titration test at least thirty days after } \\
\text { vaccination and at least three months before transport } \\
\text { Regulation (EU) } 576 / 2013 \text {; Commission Implementing } \\
\text { Regulation (EU) } 577 / 2013 \text { and Commission } \\
\text { Implementing Decision (EU) } 2019 / 294 \\
\text { - Must come from listed authorized territories } \\
\text { or third countries } \\
\text { - Must be accompanied by a health certificate } \\
\text { completed and issued by an authorized veterinarian } \\
\text { within } 48 \text { hours prior to transport } \\
\text { - Must be subjected to specific controls at veterinary } \\
\text { border inspection posts }\end{array}$ \\
\hline
\end{tabular}

For Malta, United Kingdom, Ireland and Finland, additional prerequisites must be met concerning treatment against Echinococcus multilocularis (Commission Delegated Regulation (EU) 2018/772 and Commission Implementing Regulation (EU) 2018/878). Currently, in the transition period after Brexit, all previous legislation for pets traveling to the UK and between the UK and the EU remains in effect. 
account. Since Belgium has officially been declared free from rabies since 2012 (FAVV, 2018), dogs, cats and ferrets only have to be vaccinated against rabies if they cross borders. Problems may arise in the non-vaccinated population within the country if nonvaccinated or badly vaccinated animals are imported from an endemic area, posing a serious risk to public health. Specific regulations regarding the prevention and control against rabies in Belgium are regulated in the Royal Decree on the prevention and control of rabies (RD 18/09/2016). More regulations apply for commercial transports or when the transport concerns the import from a non-EU-country. A summary of these prerequisites and legal texts involved can be found in Table 3.

\section{ILLEGAL DOG TRADE}

It is believed that a considerable part of the puppies traded to and in between countries of the European Union comes from irresponsible or malicious breeders (FECAVA et al., 2016). It is said that many of these pups and their mothers are kept in sickening conditions (McMillan et al., 2011; Yeates and Bowles, 2017). The illegal puppy trade has many faces and does not only concern cross border smuggling of hidden, non-registered pups or undeclared commercial transports slipping past inspection posts; it also involves the breeding and selling of more litters than licensed to, the excessive breeding of dams, the selling of underaged puppies (whether or not with falsified passports), and the forging or manipulation of official documents of pups in declared transports to meet the legally required conditions (Van Uhm, 2010; Four Paws International, 2013; Posch et al., 2013; Hus, 2017; Kuijpers, 2017; Wyatt et al., 2017, DogsTrust, 2018). In case underaged puppies are imported, they may have been weaned too early and may not have been vaccinated correctly, compromising their behavioral development and own health and potentially causing serious threats to human health.

\section{IMPORTANCE OF AGE ESTIMATION}

Being able to estimate the age of pups as accurately as possible is becoming increasingly important and can be a necessary tool to demonstrate potential malpractice in the prospering trade of puppies, with special focus on the age around eight weeks and around fifteen weeks. When there are doubts on the certainty of the 'alleged' age, an independently performed age assessment preferably based on a combination of several reliable methods, can give a reliable estimation. This can help official bodies to check compliance with legal provisions. It can help veterinarians in performing a better health control and, for example, apply a vaccination protocol adapted to the actual age. Puppy traders who buy foreign puppies for further sale are offered the opportunity to refuse puppies when it can be demonstrated without any doubt that these puppies are too young.

\section{TECHNIQUES FOR AGE ESTIMATION IN PUPS}

General morphological and behavioral development

Puppies go through specific developmental stages recognizable by a characteristic appearance and behavior. The major part of these developmental characteristics can only give a preliminary, rough estimation of age (Scott and Fuller, 1965; Markwell and Thorne, 1987; Serpell et al., 1995; Overall, 2013). Many obvious sensory and motor developmental milestones, such as the opening of the eyelids and ear canals or learning to walk and bark, already occur in the first weeks of life (Scott, 1958; Fox, 1964; Mosier, 1978; Hoskins and Parkington, 2001; Landsberg, 2001; Lavely, 2006), making them unusable for age assessment of pups in transport. Other features, such as growth and the shedding of the puppy coat, continue over a longer period, making the pinpointing of an exact age less probable. Moreover, the age of onset and duration can be breed-, sex- and environmental dependent (Markwell and Thorne 1987; Appleby et al., 2002; Peterson, 2011; Evans and de Lahunta, 2013a; Morrow et al., 2015). The same applies to behavioral development or the first display of a specific behavior (Svartberg, 2006; Kerswell et al., 2010; Morrow et al., 2015; Lenkei et al., 2019).

\section{Dental age}

Historically, the first method of choice for age estimation in dogs is based on dental morphology and development (Girard, 1834; Cornevin and Lesbre, 1894; Cadiot and Breton, 1924; Barton, 1939; Piérard, 1967; Habermehl, 1975; Gesierich, 2015). The alleged age is further referred to as dental age, by analogy with human sciences (forensics, archeology and dentistry) (Sehrawata and Singh, 2017; Uzuner et al., 2017; Adserias-Garriga, 2019).

Most commonly, dental age assessment is performed by visual evaluation of tooth eruption (Figure 1). This technique is easily applicable and can be immediately carried out without the need for specific technical equipment or having to sedate the puppy (Piérard, 1967; Gesierich, 2015; Modina et al., 2019). Dental eruption occurs in the time frame of interest. However, intervals in veterinary (anatomy or dentistry) handbooks (Pavaux, 1944; Nickel et al., 1975; Dyce et al., 1991; Lobprise, 1993; Barone, 1997; Hale, 2005; Evans and de Lahunta 2013b; Shoe et al., 2018) are often generalized or even simplified for easy remembering. For forensic purposes, more specific or detailed references, such as Mellanby, 1929; Arnall, 


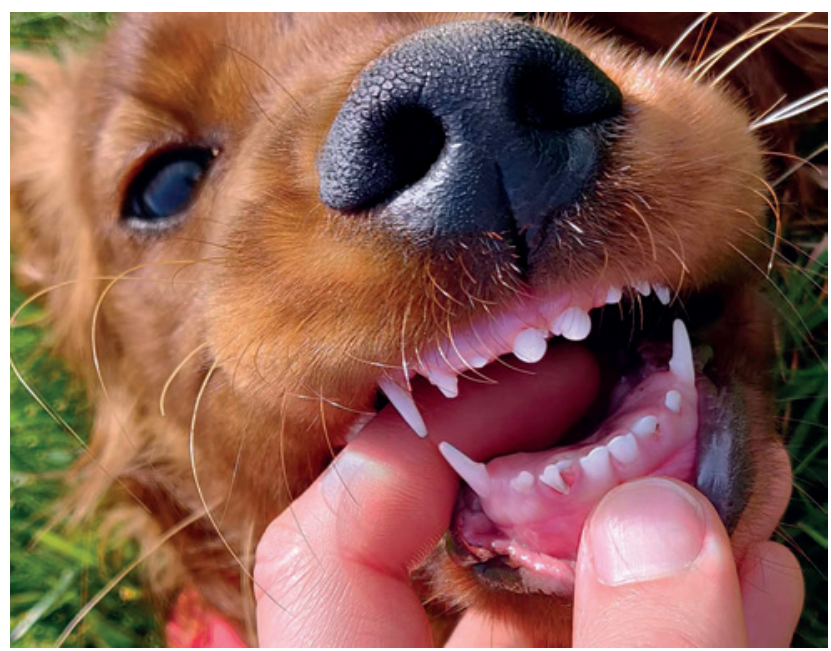

Figure 1. Permanent tooth eruption in an eighteen-weekold Irish setter puppy. The permanent first incisors are almost in occlusion and a tip of the central cusp of the second incisors is visible. Note that the deciduous second incisor of the right mandible is still present.

1961; Kremenak, 1967; Kremenak, 1969; Shabestari et al., 1967) should be used (Table 4). The normal eruption time can be disturbed as a result of primary defects in the eruption process, mechanical obstruction or displacement of a tooth germ (Stapleton and Clarke, 1999). Especially in small and brachycephalic breeds, disorders as delayed or non-eruption can oc- cur and should be kept in mind (Animoto et al., 1992; MacGee et al., 2012).

After the appearance of the complete adult dentition, the degree of tooth wear, in particular of the incisors, can be evaluated. (Girard, 1834; Cornevin and Lesbre, 1894, Seiferle and Meyer, 1942; Pavaux, 1944; Piérard, 1967: Habermehl, 1975; Barone, 1997). However, tooth wear is highly individually variable and depends on factors, such as type of diet and chewing on hard objects (Cornevin and Lesbre, 1894; Seiferle and Meyer, 1942; Piérard, 1967; Habermehl, 1975; Gesierich, 2015) and should consequently not be used anymore.

Dental changes can also be registered radiographically. The resorption of deciduous tooth roots (Hooft et al., 1979), the formation of the crown and root of permanent teeth (Hooft et al., 1979, Morgan and Miyabayashi, 1991), the closure of the apical root foramina (Morgan and Miyabayashi, 1991) and the measurement of the pulp cavity diameter (Morgan and Miyabayashi, 1991; De Smet, 2010; Marron et al., 2017) have been described in dogs. Radiographic techniques are however more invasive and (often) require sedation of the pup, technical equipment and more skilled personnel (Holmstrom et al., 2004; Dupont and DeBowes, 2009). Measuring apical root closure and pulp cavity diameter cover an older age range than the one required for pups involved in trafficking (Morgan and Miyabayashi, 1991; De Smet, 2010).

Table 4. Eruption times in days of deciduous and permanent teeth, according to Shabestari et al (1967), Kremenak (1967) and Kremenak (1969). $L=$ Left, $R=$ Right; Mand. = mandible; Max = Maxilla.

\begin{tabular}{|c|c|c|c|c|c|c|}
\hline & \multicolumn{2}{|c|}{$\begin{array}{c}\text { Shabestari, } 1967 \\
\text { Beagle } \\
\text { n=106 }\end{array}$} & \multicolumn{2}{|c|}{$\begin{array}{c}\text { Kremenak, } 1967 \\
\text { Beagle } \\
n=16 \text { (deciduous); } \\
n=27 \text { (permanent) }\end{array}$} & \multicolumn{2}{|c|}{$\begin{array}{l}\text { Kremenak, } 1969 \\
\text { Different breeds } \\
\qquad \mathbf{n = 8 0}\end{array}$} \\
\hline & Mand. & Max. & Mand. & Max. & Mand. & Max \\
\hline \multicolumn{7}{|c|}{ Deciduous } \\
\hline Id1 & $29+-3$ & $24+-3$ & 31.5 & 25.1 & $\mathrm{~L}: 30.5+-0.4 / \mathrm{R}: 30.6+-0.5$ & $\mathrm{~L}: 23.7+-0.3 / \mathrm{R}: 23.6+-0.3$ \\
\hline Id 2 & $27+-3$ & $23+-3$ & 28 & 24.2 & $\mathrm{~L}, \mathrm{R}: 26.0+-0.4$ & $\mathrm{~L}, \mathrm{R}: 22.9+-0.3$ \\
\hline $\mathrm{Id} 3$ & $25+-3$ & $23+-3$ & 26.8 & 24.7 & $\mathrm{~L}: 25.3+-0.4 / \mathrm{R}: 25.2+-0.4$ & $\mathrm{~L}: 22.5+-0.3 / \mathrm{R}: 22.5+-0.3$ \\
\hline $\mathrm{Cd}$ & $22+-3$ & $22+-2$ & 22.1 & 22.6 & $\mathrm{~L}, \mathrm{R}: 22.8+-0.3$ & $\mathrm{~L}: 22.6+-0.3 / \mathrm{R}: 22.7+-0.3$ \\
\hline $\mathrm{Pd} 2$ & $31+-4$ & $35+-4$ & 33.6 & 35.6 & $\mathrm{~L}: 33.4+-0.5 / \mathrm{R}: 32.9+-0.4$ & $\mathrm{~L}, \mathrm{R}: 34.3+-0.4$ \\
\hline $\mathrm{Pd} 3$ & $26+-4$ & $29+-4$ & 25.3 & 29.6 & $\mathrm{~L}: 22.6+-0.3 / \mathrm{R}: 23.1+-0.4$ & L, R: $28.3+-0.4$ \\
\hline $\mathrm{Pd} 4$ & $28+-4$ & $34+-4$ & 28.8 & 34.7 & $\mathrm{~L}: 25.7+-0.3 / \mathrm{R}: 26.2+-0.3$ & $\mathrm{~L}, \mathrm{R}: 31.9+-0.4$ \\
\hline \multicolumn{7}{|c|}{ Permanent } \\
\hline I1 & $117+-5$ & $115+-6$ & 118.4 & 117.7 & & \\
\hline $\mathrm{I} 2$ & $123+-5$ & $123+-6$ & 125.4 & 128.3 & & \\
\hline $\mathrm{I} 3$ & $134+-6$ & $133+-7$ & 136 & 137.3 & & \\
\hline $\mathrm{C}$ & $145+-5$ & $146+-7$ & 151.4 & 154.5 & & \\
\hline $\mathrm{P} 1$ & $129+-19$ & $106+-8$ & 119.8 & 105.2 & & \\
\hline P2 & $149+-10$ & $149+-8$ & 156.8 & 154 & & \\
\hline P3 & $156+-6$ & $153+-6$ & 158.9 & 157.5 & & \\
\hline P4 & $155+-7$ & $136+-6$ & 158 & 139.8 & & \\
\hline M1 & $128+-6$ & $132+-7$ & 132.8 & 136.2 & & \\
\hline M2 & $149+-6$ & $155+-6$ & 150.4 & 159.8 & & \\
\hline M3 & $175+-11$ & / & 178.6 & I & & \\
\hline
\end{tabular}




\section{Bone age}

In human forensics, bone age assessment by radiologically evaluating the skeletal maturity is an important tool for age estimation of children and growing adolescents (Cameron and Martin, 2012; Satoh, 2015). In minors, x-rays of the (left) hand and wrist, the Greulich and Pile-method (Greulich and Pile, 1959) or Tanner and Whitehouse method (Tanner et al., 1975) are most commonly used (Schmeling et al., 2006; Štern et al., 2017), followed by (radiologically or with MRI) assessing the clavicular bone maturation in young adults (Kreitner et al., 1998; Schmeling et al., 2006; De Tobel et al., 2019). In dogs, and by extension in all (domesticated) animals, bone age is hardly used for age determination. Of course, the presence or appearance of ossification centers and the progressive narrowing and subsequent closure of growth plates (on x-rays) (in dogs) has been well-studied, but mainly out of anatomical (PomriaskinskyKobozieff and Kobozieff, 1954; Bressou et al., 1957; Hare, 1959; Hare, 1960; Hare, 1961; Smith and Allcock, 1960; Sumner-Smith, 1966) or clinical interest (Riser, 1973; Gustaffson et al., 1975; Olsson, 1983; Fagin et al., 1992; Breit et al., 2004; Frazho et al., 2010). In veterinary archeologic (Silver, 1969) and forensics publications (Yonamine et al., 1980; Sutton et al., 2018; Modina et al., 2019), the importance of the radiological establishment of the appearance of ossification centers and closure rates of growth plates for age assessment in growing dogs have been pointed out (Figures 2A and B). Reference values in anatomical handbooks (Getty, 1975; De Lahunta and Habel, 1986; Barone, 1996; Dyce et al, 2010) and radiographic handbooks (Carlson, 1967; Ticer, 1975; Schebits and Wilkens, 1986; Kealy et al., 2011; Thrall and Robertson, 2016) are (however) based on various dog breeds making these time frames (possibly) too broad (Sutton et al., 2018, Modina et al., 2019). It should also be kept in mind that factors, such as breed, genetics, nutrition, trauma and disease, can affect skeletal development (Thrall and Robertson, 2016; Sutton et al., 2018).

\section{Biological age}

Determining the biological age is based on agerelated changes in DNA and originates from human aging research, whereby the influence of environmental factors, living conditions, etc. on life expectancy is investigated by comparing biological age with chronical (calendar) age (Jylhävä et al., 2017). In the past decade, multiple methods have been described, extending from determining the telomere length (Mather et al., 2011; Heidinger et al., 2012) to methods as T cell DNA-rearrangement (Zubakov et al., 2010; Ibrahim et al., 2016) and measuring changes in DNA methylation ('epigenetic clock') (Iacobazzia et al., 2013; Jones et al., 2015; Bacalinia et al., 2017). Many studies followed on the application of these molecular tech-
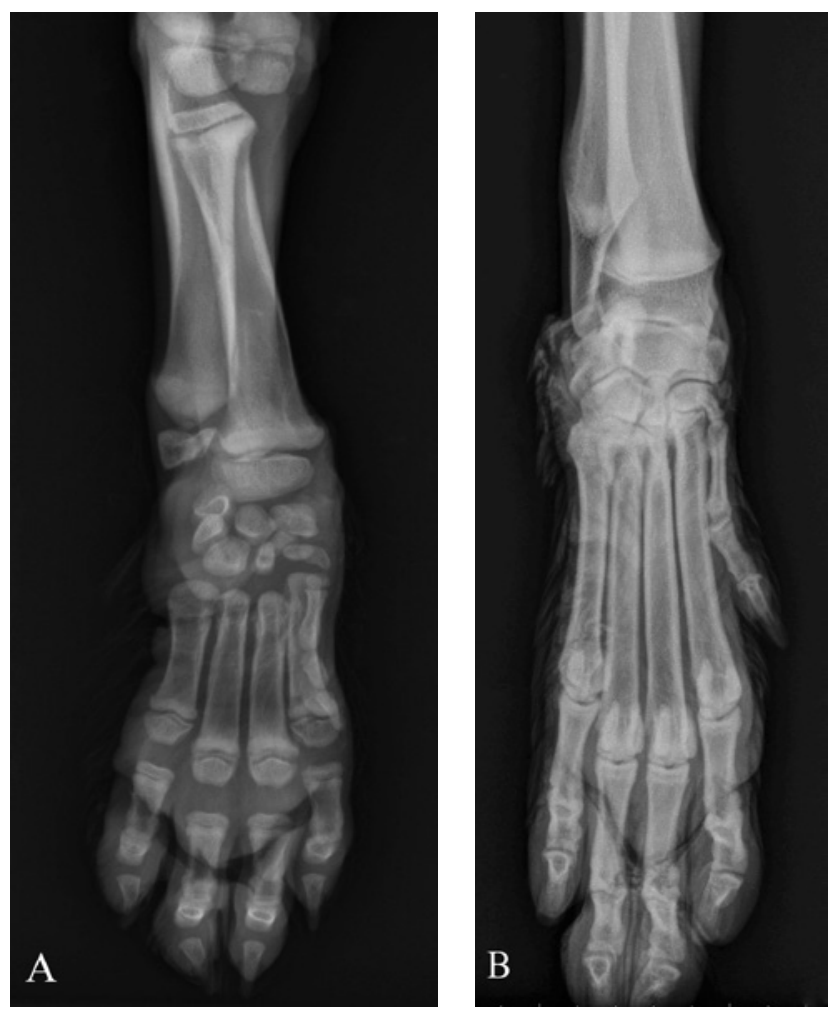

Figures $2 \mathrm{~A}$ and 2B. A. Craniocaudal radiograph of the carpus of a ten-week-old Bernese mountain dog puppy and B. A thirty-eight-week-old Bernese mountain dog juvenile. In the puppy, the growth plates are still open and ossification centers, including these of the carpal bones and the distant radial and ulnar epiphyses, are not yet fully developed.

niques in the field of human forensics, ranging from establishing age profiles based on human remains on crime scenes to age assessment in immigration fraud cases (Zubakov et al., 2016; Cassina and Clementi, 2017). Also in canids, DNA methylation has been found to correlate with age (Thompson et al., 2017). Moreover, dogs form a valuable model for human aging due to the similarities in occurring (chronic) diseases and environmental conditions (Hoffman et al., 2018), although they age at a different rate than humans (Wang et al., 2019). Nevertheless, research into the biological age of dogs is still in its infancy, and is, although promising for age estimation within all age categories, not applicable as yet.

\section{DISCUSSION}

Age assessment in legal cases requires optimal accuracy, which can be met by combining multiple independent methods in order to compensate for possible variations in any single estimation method (Schmeling et al., 2008). The obtained age interval must not only include the actual age but must also be narrow enough (Adserias-Garriga and Wilson-Taylor, 2019). Possible pitfalls should be well-documented. Not only normally occurring variability should be 
considered but also possible developmental disorders or pathologies.

A first impression of the age of puppies can be obtained by the general appearance and behavior of the pup. This is however just an impression and should always be followed by an estimation based on the dental status, which can be immediately and quite easily assessed. Subsequent determination of the radiographic bone age can confirm and even improve the age interval obtained from dental inspection (Van den Broeck and Cornillie, 2018).

The timing of tooth eruption in dogs is breeddependent, and especially in small and brachycephalic breeds, eruption disorders can occur (Seiferle and Meyer, 1942; Lawson et al., 1967; Habermehl, 1975; Colyer, 1990; Habermehl, 1994; Evans and de Lahunta, 2013b). This should be considered in order to make a reliable dental age estimate. Mostly however, published eruption data do not provide information about the examined breeds or about the number of dogs involved and make no distinction between the first breakthrough or the complete presence of a dental element. In fact, there are few original articles with data obtained from self-conducted research. Other publications contain borrowed data, often with little acknowledgment of the original source. To the authors' knowledge, only Shabestari et al. (1967) and Kremenak (1967, 1969) published extensive data, which are still accessible today. These data are based on studies performed in either beagles or a mixture of breeds. Data published in Colyer's variation of teeth (Colyer, 1990) are derived from Shabestari et al. (1967) and Kremenak (1969), combined with limited studies by Mellanby (1929) and Arnall (1961).

Most literature sources concerning the radiographic appearance of ossification centers are based on studies performed in medium to large -sized dog breeds (Modina et al, 2019). In a few recent studies on small breeds, it has been demonstrated that the time period of appearance of ossification centers in these breeds largely corresponds with the time period in medium and large breeds (Di Giancamillo et al., 2016; Modina et al., 2017; Modina et al., 2019). Closure of growth plates is more dependent on the size of the dog and occurs earlier in small breeds, whereas giant breeds can experience delayed closure (Teunissen et al., 2017; Sutton et al., 2018). Since most growth plates are still open around the age of eight to fifteen weeks, bone age estimation in these age periods are mainly based on the appearance and presence of ossification centers, a parameter which is largely breedindependent.

It is a major limitation that most of the current reference data sets for dental age as well as for bone age only describe the timing of the extremes, namely the first emergence and complete presence of a dental element or the first appearance of an ossification center and the time of closure of a growth plate, respectively. The inclusion of intermediate development stages could lead to a more exact age estimate or could narrow down the estimated age range.

\section{CONCLUSION}

It is possible to check whether puppies leaving the litter or puppies crossing EU borders have the required minimum age. Dental age assessment in combination with the general physical appearance of the puppies can give a first indication. Subsequent determination of the bone age can provide a more conclusive estimate. If necessary, a second dental and bone age assessment can be performed a week or several weeks later. Current reference values do not suffice and need to be adjusted urgently. It is especially important that more breed-specific data are provided, that more intermediate development stages are described, and that instructions are made available on how to correct for possible deviations.

\section{ACKNOWMEDGEMENT}

The authors want to thank veterinarian Elke Vleugels of the Flemish Department of Animal Welfare for checking the legislative part of the text.

\section{REFERENCES}

An extensive reference list can be obtained upon request. 